\title{
HOMENS NEGROS, FUTEBOL E MEMÓRIAS COLETIVAS EM
} MATO GROSSO

Vilma Aparecida de Pinho José Tarcísio Grunennvaldt

Resumo

As análises desse artigo centram-se nos significados que as memórias atribuem às relações étnico-raciais no futebol, a partir das lembranças de ex-jogadores negros campeões no estado de Mato de Grosso que atuaram entre os anos de 1950 a 1970. A metodologia utilizada foi a história oral, orientada por perguntas abertas sobre futebol, sociabilidades e relações étnico-raciais. Utilizamos fotografias para verificar as equipes no que se refere à raça/cor e a classificação nos certames nos quais participaram os entrevistados. Os resultados indicam que as memórias buscam contrapor uma história de [in]visibilidade do negro. Nesse sentido, os exjogadores fazem releituras de si e se valem da memória para inscrever a sua história do lugar de protagonista na história do esporte. Os sentidos que emergem da memória rompem com a noção de subalternidade racial para uma perspectiva de reconhecimento e valorização coletiva.

Palavras-chave: futebol; memórias coletivas; relações raciais; sociedade

\section{BLACK MEN, SOCCER AND COLLECTIVE MEMORIES IN MATO} GROSSO

\begin{abstract}
The analysis of this article is based on the meanings that memories give to ethnic- racial relations in football from memories of black former players champions in Mato Grosso state that played between the years of 1950 to 1970 . The used methodology was the oral history guided by open questions about football, sociability and ethnic-racial relations. It was used photographs to verify the teams in terms of race/color and ranking in competitions in which the interviewed players participated. The results show that memories seek to counteract the history of (in) visibility of black people. In this sense, the former players reinvented themselves and rely on memory to up his story of the protagonist place in the history of the sport. The meanings that emerge from memory break with the notion of racial subordination to a perspective of recognition and collective appreciation.
\end{abstract}

Keywords: football; collectives memories; racial relations; society

\section{HOMBRES NEGROS, FÚTBOL Y RECUERDOS COLECTIVOS EN MATO GROSSO}

Resumen

Los análisis de este artículo se centran en los significados que las memorias atribuyen a la relación étnicoraciales en el futbol a partir de los recuerdos de exjugadores negros campeones en el Estado de Mato grosso que actuaron entre los anos de 1950 a 1970. La metodología utilizada es la historia oral orientada por preguntas abiertas sobre futbol, sociabilidad y relaciones étnico-raciales. Utilizamos fotografías para verificar los equipos en lo que se refiere a la raza/color y a la clasificación en los campeonatos en los cuales participaron los entrevistados. Los resultados indican que las memorias buscan contraponer una historia de invisibilidad del negro. En ese sentido, los exjugadores hacen relecturas de si y se valen de la memoria para inscribir su historia del lugar de protagonista del deporte. Los sentidos que surgen de la memoria rompen con la noción de subalternidad racial para una perspectiva de reconocimiento y valorización colectiva.

Palabras clave: futbol; memorias colectivas; relaciones raciales; sociedad 


\section{INTRODUÇÃO}

O objetivo principal da pesquisa foi analisar as memórias dos ex-jogadores negros que atuaram entre as décadas de 1950 a 1970 na cidade de Cuiabá. As análises desse artigo centram-se nos significados que as memórias atribuem às relações étnico-raciais no esporte, no qual se conjugavam as pressões econômicas e as sutilezas da discriminação racial. Nesse sentido, analisamse as memórias de ex-jogadores negros que atuaram no futebol amador e profissional.

Ao considerarmos as memórias coletivas, analisaremos as relações étnico-raciais em face dos processos de reencontros que emergem das lembranças e dos significados de ser ex-jogador negro campeão. Nossa compreensão de memória coletiva se fundamenta nos pressupostos de Halbwachs (2006, p. 72) para quem a memória é coletiva "[...] ainda que se trate de eventos em que somente nós estivemos envolvidos e de objetos que somente nós vimos". É importante destacar que o sentido de memória coletiva para o autor decorre das relações, mas também da necessidade da reconstituição das lembranças com a rememoração presencial do espaço, objeto, pessoas e sentimentos, reconhecidos pelo indivíduo e pelo grupo. Diz o autor que "É preciso que estejamos ou que encontremos condições que permitam combinar melhor a ação das influências para que a lembrança reapareça e seja reconhecida" (HALBWACHS, 2006, p. 52).

As condições, segundo o autor, são o reencontro do indivíduo com o espaço / objeto ou sentimentos que fazem ligações e formam um conjunto, um quadro que corresponderá às lembranças de detalhes de acontecimentos do passado. Nesse sentido, o destaque que se faz pelo reconhecimento do lugar não significa um reconhecimento de movimento "da percepção", como em Bergson (apud BOSI, 1994). Mas da recolocação de muitas séries de pensamentos que atravessam o espírito, que ligam a pessoa às outras pessoas e aos grupos aos quais ainda se está ligado, porque posso me pôr de novo em seu ponto de vista, no qual o outro é o grupo dos que habitam ou passam pela cidade, dos quais hoje me vejo fazendo parte temporariamente, como fiz outrora (HALBWACHS, 2006). Nesse caso, não há uma percepção e uma lembrança, mas o restabelecimento de contatos para que a lembrança reapareça.

A lembrança é a transformação do ambiente em uma imagem rica de consciência. Entretanto, a reorganização interna decorre do "reencontro", ou seja, da associação da matéria a lógicas de representações coletivas. Por isto, a lembrança é uma unidade interna que se destaca de combinações de diversos ambientes e se transforma em imagem. Mas isso só é possível devido às forças dos contatos que permanecem:

Esse encontro é em si um fato objetivo, não apenas um jogo de imagens, mas o encontro efetivo de representações e sentimentos objetivos que são os objetos da natureza, observáveis de fora, como as coisas materiais. Assim, a intuição sensível e a ligação que ela estabelece no momento e por um momento em nossa consciência se explica pela associação que existe ou se estabelece entre objetos fora de nós. [...]

A lembrança está ali, fora de nós, talvez dispersa entre muitos ambientes. Se a reconhecemos quando reaparece inesperadamente, o que reconhecemos são as forças que a fazem reaparecer e com as quais sempre mantivemos contatos. (HALBWACHS, 2006, p. 59).

\footnotetext{
1 Observe-se que Bosi (1994) discute a memória a partir de Bergson indicando que este autor considera que o movimento da percepção faz o sujeito se situar no mundo vivido. Mas a memória, de acordo com Bergson, é feita de pensamentos do interior (quase do inconsciente), evocados pelo esforço do indivíduo. Essa posição teórica é diferente, mas complementa a de Halbwachs (2006), utilizada nessa pesquisa.
} 
As memórias de ex-jogadores negros de futebol são memórias subterrâneas, contadas a partir dos sujeitos, [in]visibilizados na história oficial ${ }^{2}$. O processo de lembrar implica uma releitura das experiências evocadas pelos indivíduos. Por isso, as memórias, a nosso ver, compreendem uma dimensão política dos sujeitos como força que aglutina e que os liga à história e à sociedade. Dessa maneira, embora a memória seja uma reconstrução espontânea, é dirigida pelos significados que a compreensão coletiva engendra em determinado tempo / espaço.

Mas é imprescindível que se inteirem do seu passado, dos quadros de sua referência que foram criados no tempo por si e por outras gerações. A memória leva à ressignificação das experiências e, nesse sentido, a história e a historicidade são a descoberta do próprio indivíduo que traça, desde o começo, a trilha do pensamento e os caminhos a seguir. Continua o autor afirmando que o espaço de criação, que se realiza na luta do indivíduo pela descoberta de sua historicidade, faz-se de ações e no campo da política. O passado, a história é uma força aglutinadora, na qual nos apoiamos: “[...] apoiar-se, e debruçar-se é próprio de um ser consciente" (DIAS, 2011, p. 134).

Para tanto, é necessário que antes o sujeito se inteire do seu passado, dos quadros de sua referência que foram criados no tempo por si e por outras gerações. Nos estudos da condição humana, Arendt (1978) nos permite compreender um pouco esse processo, ao chamar atenção sobre a importância da memória: nos termos seguintes, a autora reforça sua compreensão:

A memória, o poder do espírito de ter presente o que é irrevogavelmente passado e por isso ausente dos sentidos, foi sempre o exemplo paradigmático mais plausível da capacidade do espírito para tornar presentes os invisíveis. Em virtude desta capacidade, o espírito parece ser ainda mais forte do que a realidade; opõe a sua força à inerte futilidade de tudo o que está sujeito à mudança; acolhe e recolhe aquilo que de outro modo estaria condenado à ruína e ao esquecimento. A região temporal em que este salvamento tem lugar é o Presente do eu pensante. [...] (ARENDT, 1978, p. 18).

No contexto da historicidade, o indivíduo é levado a agir sobre sua vida, suas condições, e isso depreende um processo criativo que tem origem na compreensão do passado. Nesse sentido, foi interesse do estudo verificar o que lembram os ex-jogadores negros no que se refere às relações étnico-raciais, tendo em vista a raça como uma construção sociológica, e o racismo como ideologia da inferioridade racial do negro, elementos (sociais e ideológicos) que interferem sobremaneira na compreensão de si e na alocação social dos sujeitos ${ }^{3}$ na sociedade brasileira ${ }^{4}$.

O futebol envolve as dimensões humanas, sociais, culturais (religiosas) e coletivas que dão sentidos à vida (FRANCO JR., 2007). No Brasil, em geral, e no Mato Grosso, o futebol tornou-se não apenas uma linguagem poderosa, mas um "tempo e espaço" para fazer as populações se misturarem, combinarem suas ideias e sentimentos. Compreende um rito festivo, de natureza cooperativa, que causa estranheza e perplexidade: como um povo mergulhado na extrema desigualdade e exploração pode ser tão generoso, criativo e construtivo? (MURAD, 1996). Faz

\footnotetext{
2 Segundo Gonçalves (2011, p. 34), a memória subterrânea é utilizada por Pollak para demarcar as atrocidades sofridas pelos "sobreviventes do campo de concentração de Auschwitz" na Segunda Guerra Mundial. Essa noção de memória contrapõe a história oficial que nega (ou invisibiliza) o protagonismo social de grupos que sobreviveram e resistiram a situações desumanas de sofrimentos e opressões. Trata-se de dar visibilidade à história dos silenciados pela história tradicional que dá pouco ou nenhum valor às experiências humanas.

${ }^{3}$ Lembramos aqui que ser negro em ascensão social no Brasil se efetiva em um processo de conflito psíquico, conforme Souza (1983), pois o negro é impelido a se lembrar que é negro pelos cânones da inferioridade racial criada pelas concepções racistas. Para Jurandir dos Santos Costa (1983), ser negro é ter de enfrentar um processo cotidiano de violência, pois o corpo se torna marca de uma inferioridade registrada no inconsciente da pessoa, cujo fenótipo não é compatível com os valores que a sociedade oferece.

4 Para estudos sobre raça, teorias racialistas e a construção social do racismo no Brasil ver Pinho (2010).
} 
parte das “[...] representações coletivas, arquetípicas de forte densidade simbólica para a realidade dos povos, de incalculável impacto para o imaginário humano" (MURAD, 1996, p. 66).

No contexto do futebol, as lembranças de cada ex-jogador são um ponto de vista do coletivo, as quais recriam a sensação do reencontro. As lembranças são reconstituídas e evocadas a partir das memórias individuais que guardam pontos em comum com o coletivo, os quais acessam facilmente pensamentos, ideias, percepções e emoções do grupo. Pode-se supor, como isso acontece:

Porque estão num terreno comum, no sentido de que o que nos é assim familiar ou facilmente acessível, é igualmente familiar para os outros. A ideia que mais facilmente representamos é composta de elementos tão pessoais e particulares quanto desejarmos, é a ideia que os outros fazem de nós, e os fatos de nossa vida que estão sempre mais presentes para nós também foram gravados na memória dos grupos que nos são mais chegados. (HALBWACHS, 2006, p. 66).

Os grupos de ex-jogadores, homens negros, mantiveram-se juntos por vários anos atuando em equipes distintas, mas repletas de contatos. O convívio foi intenso durante o período de atuação como jogadores, porém, as relações ficaram mais reduzidas após essa fase, visto que cada um pegou caminhos diferentes, embora convergentes. Percebeu-se a importância dos contatos e das relações que permaneceram na reconstrução das lembranças, mas também muitas "imagens" narradas a partir de um estado interno de latência de memória, como em Bergson (apud BOSI, 1994), que afloraram do inconsciente ao consciente pautadas pelos passos das histórias de vida de cada um.

\section{A ENTRADA EM CAMPO: OS JOGADORES E O MÉTODO DA PESQUISA}

Entrevistamos dez ex-jogadores negros. As entrevistas foram feitas em suas residências e apenas um deles nos recebeu no local de trabalho. Fizeram-se as gravações das conversas em aparelho de telefone celular e, também, em um gravador; em seguida, fez-se a transcrição na íntegra das conversas, tendo em vista as análises dos dados obtidos.

Os dados que foram analisados são referentes às memórias dos ex-jogadores, que retratam pela fonte oral suas lembranças do esporte, e transformadas por nossa compreensão da história do esporte, a partir desses pontos de vista. A pesquisa de campo teve início no ano de 2015, e nossas primeiras aproximações com o "campo" foram repletas de cuidados, pois temíamos não conseguir os contatos com os ex-jogadores de futebol. Porém, após uma visita à Federação Matogrossense de Futebol, o quadro se mostrou bastante promissor no sentido de conseguirmos os contatos.

As entrevistas ocorreram entre os anos de 2015 a 2017 e foram norteadas "[...] por um equilíbrio de perguntas abertas e fechadas" (THOMPSON, 1992, p. 260) com a finalidade de registrar, pela fonte oral, o cotidiano dos jogadores, suas relações, o significado do futebol em suas vidas e as experiências raciais no contexto esportivo. Utilizamos fotografias na pesquisa para conhecer as equipes e fazer a classificação racial dos atletas.

A ética na pesquisa ocorreu pelo atendimento aos direitos humanos e à dignidade humana; por isso, a identificação dos ex-jogadores (colaboradores da pesquisa) foi feita de duas formas nesse artigo: primeiro pelo termo depoente, quando se tratou de narrativa; segundo, pelo nome público, conforme era utilizado no futebol, quando se tratou da menção por colegas de equipe; e, na Tabela 2 , na qual consta a formação e a profissão desempenhada pelos ex-jogadores. Essas duas formas de identificação e a utilização de imagens foram devidamente autorizadas pelos ex-jogadores com a assinatura de um documento.

Observe que a idade atual dos ex-jogadores aparece na Tabela 1, mas a faixa-etária em que atuaram no esporte foi durante a juventude, mais precisamente entre as idades de 14 a 28 anos. 
DOI: $10.12957 /$ teias. $\%$ Y.49716

Tabela 1: Idade e duração de tempo como jogador e a equipe principal na qual atuou

\begin{tabular}{l|c|c|l} 
Nome & Idade & $\begin{array}{c}\text { Tempo que } \\
\text { jogou }\end{array}$ & Clube/Equipe \\
\hline Depoente 1 & 74 & 10 anos & Mixto Esporte Clube \\
\hline Depoente 2 & 73 & 3 anos & Mixto Esporte Clube \\
\hline Depoente 3 & 64 & 3 anos & Mixto Esporte Clube \\
\hline Depoente 4 & 65 & 8 anos & Mixto Esporte Clube \& Esporte Clube Operário \\
\hline Depoente 5 & 65 & 14 anos & Mixto Esporte Clube \\
\hline Depoente 6 & 74 & 12 anos & $\begin{array}{l}\text { Clube Esportivo Dom Bosco \& Clube Atlético } \\
\text { Matogrossense }\end{array}$ \\
\hline Depoente 7 & 76 & 14 anos & Mixto Esporte Clube \\
\hline Depoente 8 & 63 & 10 anos & Esporte Clube Operário \\
\hline Depoente 9 & 68 & 15 anos & Clube Esportivo Dom Bosco \\
\hline Depoente 10 & 72 & 8 anos & Clube Atlético Matogrossense e Mixto Esporte Clube
\end{tabular}

Fonte: Dados organizados pelos autores

Saliente-se que havia uma certa fidelidade por parte dos jogadores aos clubes, fato muito comum à época, especialmente nos grandes clubes, quando o futebol era amador. A esse respeito, no contexto nacional, houve o primeiro turbilhão devido à troca repentina de clube em 18 de setembro de 1927, quando os torcedores do Flamengo organizaram o enterro (simbólico) de Penaforte, que havia trocado o Flamengo pelo América, porque este último lhe ofereceu mobília de quarto para se casar (MÁRIO FILHO, 2003).

A respeito disso, podemos conjecturar que o acirramento dos processos competitivos mediante as organizações das ligas e campeonatos nacionais e internacionais possibilitou aos jogadores lograr mais oportunidades ${ }^{5}$. Mas enquanto o futebol tinha pouca importância econômica e simbólica, os jogadores, quando obtinham a vitória, ainda aceitavam como gratificação um bom jantar e o dobro desse valor em "bicho". Entretanto, na medida em que a sociedade modifica seus valores e o Estado brasileiro empreende uma política industrial nacionalista, ocorre no futebol na década de 1930 do século passado a passagem de amador para profissional (PIMENTA, 1999).

O processo que transformou o futebol e os clubes esportivos em empresas, de certa forma foi benéfico aos jogadores negros que conseguiam, com mais legitimidade, negociar suas performances (FRANCO JR., 2007). No contexto desenvolvimentista, os jogadores percebem que a "camisa" não joga e começam a barganhar condições mais favoráveis para si, pois não havia vitória sem o jogador. Com isso, cria-se a noção de "a vitória do jogador sobre a camisa", em contraponto ao que se tinha de valor - que era o amor ao clube e que fazia o torcedor brigar na geral, na arquibancada e o jogador se matar em campo (MÁRIO FILHO, 2003).

Em relação ao desenvolvimento do futebol em Matogrosso, houve a correlação de possibilidades que variou entre a prontidão dos "atletas" aos dispêndios pessoais dos

\footnotetext{
${ }^{5}$ Pimenta (1999) destaca que a estrutura do futebol brasileiro pode ser compreendida em face das mudanças no eixo político (do regime militar ao democrático) e econômico do país, destacando seus marcos principais: 1 - O caso do Clube dos 13: foi uma reação dos Grandes Clubes brasileiros à tradição autoritária dos governos militares que ignorou o regulamento do campeonato nacional, rompendo com a política paternalista brasileira representada pela Confederação Brasileira de Futebol (CBF), quando começam a buscar por conta própria recursos para alcançar seus objetivos. 2 - A Lei Zico / Lei n. 8.672/93 que repercutiu mudanças radicais no futebol como: (a) o fim do escravismo na relação clube / jogador, dando mais autonomia aos jogadores no término dos contratos; (b) o rompimento com o modelo intervencionista do Estado às Confederações, às Federações e aos Clubes; (c) o surgimento do Clube / empresa. 3 - Por último, a "Lei Pelé" ou "Lei do Passe" - que criou a extinção do passe, ou seja, do vínculo eterno entre jogador e clube.

${ }^{6}$ Chamava-se "prata da casa" ao jogador que dava tudo pelo clube. Geralmente tinha nascido, crescido e coberto de glória o clube. (MÁRIO FILHO, 2003, p. 158).
} 
administradores e torcedores e a intervenção do Estado, com a construção do Estádio Presidente Dutra no ano de 1952. Antes desse Estádio, as primeiras competições de futebol eram feitas no campo do Colégio Estadual. Mas a inauguração dele, atrelada aos serviços da Federação Matogrossense de Futebol, deu estímulo ao esporte, que começou a ter sistematicamente campeonatos e amistosos nacionais e internacionais, até o início da década de 1970, quando se inaugura o Estádio Governador José Fragelli - o Verdão - e também quando o esporte e a sociedade desenvolvem outras configurações, das quais a maioria de nossos entrevistados não fez parte como jogadores.

O Estádio Gaspar Dutra (Dutrinha) foi construído na esteira da construção do Maracanã no Rio de Janeiro, em 1950, ambos impulsionados pela Copa do Mundo que ocorreria no Brasil. A ação dos jogadores e administradores do futebol, naquela época, repercutiu nos modos de divertimento da população cuiabana, que se agregava em torno do futebol por interesse na diversão.

\section{A PRESENÇA DE JOGADORES NEGROS NO FUTEBOL}

Um de nossos depoentes se lembrou que o futebol era "triste" (ruim, sem estrutura), pois não dava aos jogadores condições para jogar e nem rendimentos salariais: mas "[...] era muito amor no coração. Hoje, o jogador possui tudo, roupas, bolas; antigamente as bolas eram costuradas por fora e, em relação às de hoje, não tinham peso ideal. As chuteiras eram fabricadas aqui mesmo e não tinham sistema de conforto na sua estrutura” (Depoente 1). As camisas são tão leves: “[...] na nossa época eram de algodão, quando chegava o final do primeiro tempo a camisa estava pesando 5 quilos, hoje são umas sedas, leves. Hoje os atletas se concentram nos melhores hotéis, têm alimentação, têm um preparador físico". (Depoente 2).

Essas narrativas retratam um pouco da ínfima infraestrutura que se disponibilizava àquela época aos jogadores. Mas o futebol, assim como outros aspectos da cultura cuiabana, como rádio, teatro, cinema, estava iniciando. De fato, a cidade nesse período se encontrava em franca organização, inclusive de sua arquitetura, cujos prédios foram reformados e as ruas alargadas. $\mathrm{O}$ prédio antigo da Igreja Matriz, assim como outros do centro, foi demolido e substituído por outro, à época, considerado mais moderno.

Os jogadores eram atores, ou seja, protagonistas no futebol, e as evidências são os resultados nos diversos certames em que jogaram. O futebol se desenvolveu pela eficácia desses atletas, que garantiam o espetáculo esportivo nos diversos clubes que representavam no estado. A imagem seguinte representa significativamente a composição de raça / cor das equipes que são compostas por alguns de nossos entrevistados. 
Figura 1: Equipe campeã de Mato Grosso no ano de1960

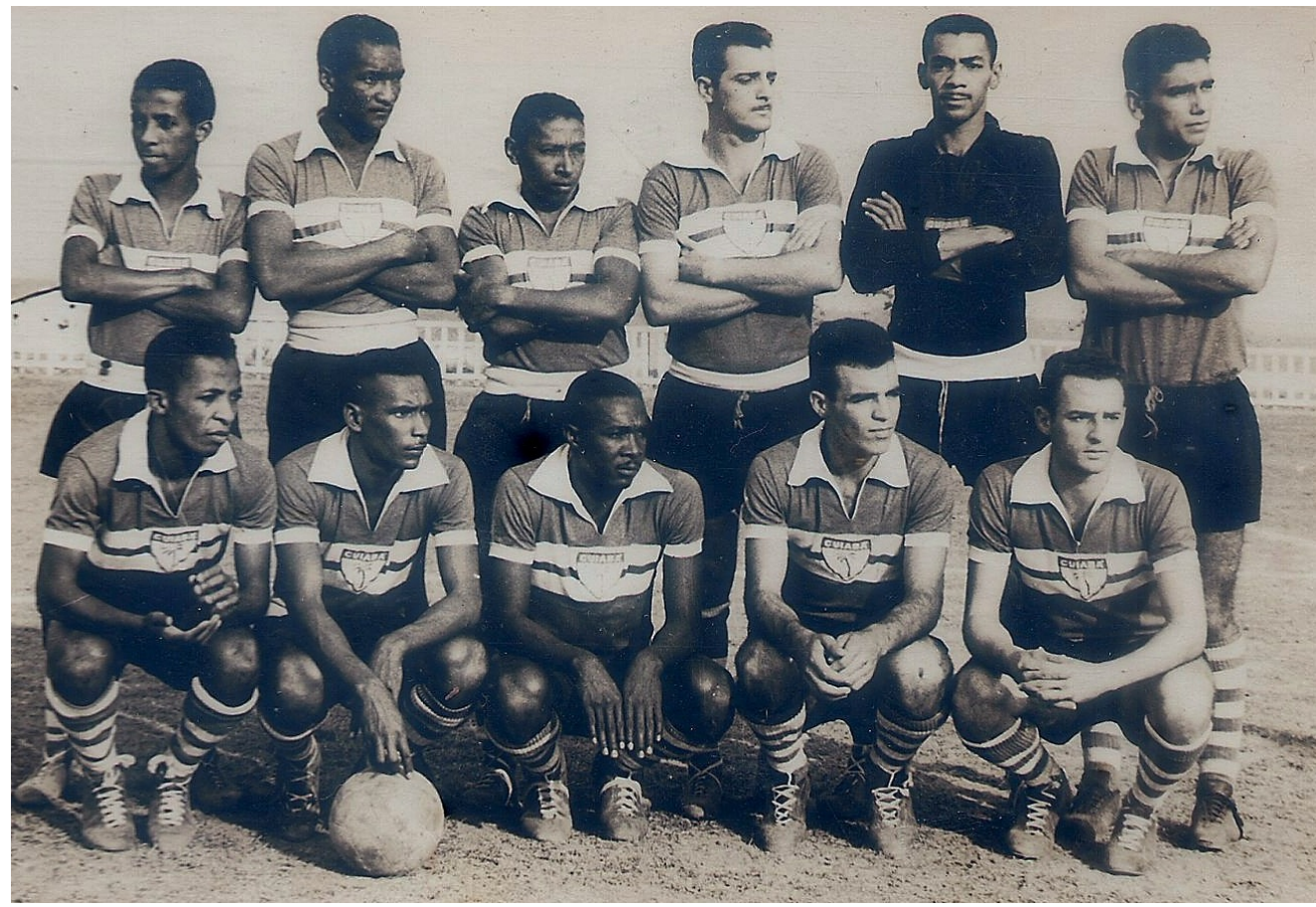

Fonte: Álbum de fotografias do acervo pessoal do ex-jogador Glauco.

A composição por homens negros foi encontrada nas diversas equipes de futebol, desde os clubes até as seleções do estado. A equipe matogrossense campeã de 1960 era composta majoritariamente por negros, conforme se observa na imagem, da esquerda para a direita em pé estão: Pelé; Felizardo; Bugrinho; Fulepa; e agachados, Ariel, Nato e Fião. Os declarados mestiços são Portela, Baicerê, Ruiter e Emílio. A identificação racial foi feita pela pesquisadora e pelos exjogadores ${ }^{7}$ entrevistados, que fizeram a autodeclaração racial e atribuíram a raça / cor dos colegas de futebol em mestiços e branco (cor branca).

De nossa compreensão, verdadeiramente, nossos entrevistados não só participaram dos principais campeonatos da época, como foi pela atuação deles que o futebol desenvolveu proporções quanti e qualitativas no estado. O depoente 1 foi campeão pelo Mixto em 1959, quando o Clube fez um campeonato invicto. O depoente 4 conquistou em 1970 o tetra-campeonato, sendo em 1967 e 1968 no Clube Esportivo Operário, e em 1969 e 1970 no Mixto Esporte Clube; o depoente 5, jogador que atuou entre meados da década de 1960 até meados da década de 1970, conquistou vários títulos, inclusive o bi-campeonato do Mixto Esporte Clube em 1969 e 1970; os depoentes 6 e 10 foram campeões no Clube Atlético Matogrossense em 1960, sendo que o primeiro jogador continuou sua carreira no futebol do estado, e foi campeão também pelo Dom Bosco, colaborando várias vezes nos campeonatos estaduais, representando o Mato Grosso; foi campeão no Clube Esportivo Operário em 1963 e no Clube Dom Bosco em 1964. O depoente 3 foi vicecampeão no Mixto Esporte Clube, em 1963.

Nesse sentido, a estrutura do esporte se produzia na relação de interdependência dos indivíduos, especialmente, pelo nível de harmonia obtida entre eles, pois sabiam conjugar seus

\footnotetext{
${ }^{7}$ Destaque-se que, dessa equipe, entrevistamos três ex-jogadores a saber: Felizardo, Nato e Fião, conforme a Tabela 1: Idade e duração de tempo como jogador e a equipe principal na qual atuou.
} 
talentos físicos e táticos na tensão do jogo, aspecto esse fundamental que exemplifica a sociologia de Norbert Elias.

Os jogadores atuaram com contratos de trabalho, mas, principalmente no futebol amador. Entretanto, ainda que estivessem na rubrica de profissional, não podiam garantir o sustento de suas vidas com o futebol. O depoente 8 (jogador do Operário de Várzea Grande) terminou a carreira de futebolista na década de 1980, já com mais de 30 anos de idade, em uma condição econômica favorável devida ao futebol, porque ganhava dinheiro tanto dos contratos com o clube quanto pelos seletivos e jogos de finais de semana.

A performance no futebol, possivelmente, estava acentuada no significado de cidadania, que não se dava mediante o desenvolvimento de políticas públicas de Estado, mas por meio de trocas, como aquelas que se pactuavam em sociedades tradicionais, em que a ausência do Estado demandava outros mecanismos de organização, nas quais se utilizavam contratos sociais valorados em sentidos morais, éticos, afetivos e econômicos também.

Não tivemos acesso aos contratos dos jogadores, mas esse depoente e os depoentes 9 e 5 afirmaram que recebiam porcentagem no início da temporada e que, no decorrer dos certames, recebiam prêmios e outras recompensas. Porém, mesmo recebendo alguns proventos, esses exjogadores buscaram na formação escolar e no trabalho a sustentabilidade de suas condições humanas.

Tabela 2: Formação e trabalho dos ex-jogadores

\begin{tabular}{|l|l|l|l|l|}
\hline \multicolumn{1}{|c|}{ Nome } & $\begin{array}{c}\text { Atuação no } \\
\text { futebol }\end{array}$ & \multicolumn{1}{|c|}{$\begin{array}{c}\text { Grau de } \\
\text { escolaridade }\end{array}$} & \multicolumn{1}{|c|}{ Formação } & \multicolumn{1}{|c|}{ Trabalho } \\
\hline $\begin{array}{l}\text { Natanael } \\
\text { "Nato" }\end{array}$ & Profissional & Nível superior & $\begin{array}{l}\text { Educação } \\
\text { Física }\end{array}$ & $\begin{array}{l}\text { Professor de Ensino Superior e } \\
\text { Médio }\end{array}$ \\
\hline Rômulo & Profissional & Nível superior & Direito & Advogado \\
\hline $\begin{array}{l}\text { Ricardo } \\
\text { (Gaguinho) }\end{array}$ & Profissional & Ensino Médio & $\begin{array}{l}\text { Técnico em } \\
\text { mecânica }\end{array}$ & Oficial de justiça \\
\hline $\begin{array}{l}\text { Admir } \\
\text { Moreira }\end{array}$ & $\begin{array}{l}\text { Amador / } \\
\text { Profissional }\end{array}$ & Nível Superior & $\begin{array}{l}\text { Educação } \\
\text { Física }\end{array}$ & $\begin{array}{l}\text { Professor; Funcionário público } \\
\text { de órgãos ligados ao esporte }\end{array}$ \\
\hline Accácio & Amador & Ensino Médio & Administração & $\begin{array}{l}\text { Administrativo de empresa de } \\
\text { seguros }\end{array}$ \\
\hline Albino & $\begin{array}{l}\text { Amador / } \\
\text { Profissional }\end{array}$ & $\begin{array}{l}\text { Ensino } \\
\text { Fundamental }\end{array}$ & - & $\begin{array}{l}\text { Atividades manuais em empresas } \\
\text { privadas }\end{array}$ \\
\hline Marcelo & Amador & Nível superior & Arquitetura & Arquiteto aposentado \\
\hline Glauco & $\begin{array}{l}\text { Amador / } \\
\text { Profissional }\end{array}$ & Ensino Médio & - & $\begin{array}{l}\text { Aposentado como funcionário } \\
\text { público do estado }\end{array}$ \\
\hline Felizardo & $\begin{array}{l}\text { Amador / } \\
\text { Profissional }\end{array}$ & $\begin{array}{l}\text { Ensino } \\
\text { Fundamental }\end{array}$ & - & $\begin{array}{l}\text { Aposentado como funcionário } \\
\text { público do estado }\end{array}$ \\
\hline "Fião" & $\begin{array}{l}\text { Amador / } \\
\text { Profissional }\end{array}$ & $\begin{array}{l}\text { Ensino } \\
\text { Fundamental }\end{array}$ & - & $\begin{array}{l}\text { Aposentado como funcionário } \\
\text { público do estado }\end{array}$ \\
\hline
\end{tabular}

Fonte: Dados organizados pelos autores

\footnotetext{
${ }^{8} \mathrm{Na}$ teoria da configuração, as relações são permeadas de poder. Há, na concepção do autor, "[...] o firme reconhecimento de que o poder é polimorfo e multifacetado”. Nesse sentido, o poder existe em qualquer configuração, mas se modifica conforme as posições que os indivíduos adquirem. Ou seja, não é algo fixo, reificado. No futebol, o poder, certamente, oscilou entre o branco e o negro, dada a importância das duas partes no processo de desenvolvimento do esporte. Nem o branco nem o negro tiveram autonomia total para fomentar o futebol, pois todo o processo dialético fora feito por indivíduos que formavam uma configuração, cujo pressuposto é a interdependência das partes (ELIAS, DUNNING, 1992).
} 
Ao analisar o processo de ascensão social dos jogadores em conformidade com suas lembranças, afirma-se que houve um conjunto de forças pessoais, sociais, culturais e políticas que culminaram no processo de autorrealização de cada um deles. Nesse sentido, seria reducionista afirmar que o futebol, propriamente dito, foi o trampolim de ascensão social e autorrealização do grupo, pois as memórias dos depoentes são testemunhos de esforços pessoais e coletivos que agregaram em trabalhos, formação, reconhecimentos e autoestima, por seus talentos especiais.

\section{MEMÓRIAS DAS RELAÇÕES ÉTNICO-RACIAIS: FUTEBOL E A [RE] CONSTITUIÇÃO DE [SI] PELO COLETIVO}

Podemos afirmar que os jogadores continuam a fazer parte do grupo e, assim, conseguem "[...] criar um conjunto de lembranças que se relaciona uma com as outras" (HALBWACHS, 2006, p. 34). Assim, há vários eventos vividos no futebol que são [re]construídos pela memória como uma sensação de reencontro. Nesse sentido, as lembranças do futebol têm um significado real porque são evocações de sentimentos que ficaram marcados nos espíritos dos jogadores. Como não se lembrar das emoções se estavam ligados à paixão pelo esporte? Como falar de futebol sem lembrar dos sentimentos que faziam agir os seres humanos em torno das ações?

Futebol era paixão. A gente jogava porque gostava. Primeiro, que não tinha mídia. Era rádio e jornal. Escrito e falado. Você jogava a troco de 10, 20 ou 30 reais $(s i c)$, quando ganhava, quando perdia você não ganhava nada. Ou então um emprego no governo, né? Ter um emprego era uma grande coisa na época. Ter seu salário do serviço, não do time que você jogava. Era tudo por amor mesmo... A gente jogava por amor mesmo, sabe? (Depoente 2).

Era um círculo de amizade sensacional. Era principalmente quem jogava em time de ponta, como o Mixto. Financeiramente você não ganhava nada, quase nada. Mas o círculo de amizade que tinha era fantástico, sensacional e recompensava. (Depoente 1).

De acordo com essa narrativa, a energia que movia o futebol era a paixão, pois o "miserê" (Depoente 2) era total. Pode-se destacar que os afetos trazidos pela memória dos ex-jogadores são "emoções-sentimentos-paixão", tríade que, embora seja mobilizada pela função do corpo orgânico, é duradoura, histórica e cultural, pois há nessa memória afetiva uma inscrição de significação da história subjetiva que define os sentimentos individuais e coletivos ao mesmo tempo, e que marcam as afetividades dessa geração com o esporte, a qual, segundo o posicionamento deles, difere das gerações mais novas, que se mobilizam em torno do futebol mais por dinheiro do que por amor.

A emoção é uma espécie de afeto que difere da paixão: “[...] caracteriza-se por ser momentânea, por gerar sensações complexas como surpresa, esperança, abatimento, paixão mobilidade, a unidade da vida do espírito e a totalidade da consciência" (ARREGUY, 2011, p. 94). Essa autora faz abordagens da emoção e da paixão a partir da filosofia e afirma que o efeito da emoção depende da intensidade, qualidade e duração da paixão. Dessa maneira, as paixões seriam superpostas por emoções, “[...] de acordo com a premência do interesse e com a agitação do pensamento".

A estética do corpo, suas sensibilidades e expressões vinham de uma técnica de uso do corpo fabricado na história de vida, o qual pelas exigências das brincadeiras e jogos (inclusive de futebol) desenvolveu a instrumentalização para empreender a força e a resistência (preparo físico) e eficácia no jogo (pelo domínio dos fundamentos e táticas do futebol). Esse corpo foi marcado por uma pedagogia que o potencializou na dialética das ínfimas condições da época. Como indica Fraga (2004), a sociedade produz necessidades que se configuram como uma tecnologia política que marca as práticas corporais. 
No esporte, especialmente no futebol, a linguagem corporal é essencial, e exige que sejam evocados e treinados, antes das partidas, a forma de uns e de outros, os riscos de ferimento, a tática a empregar etc. (HOLT, 2009). Foi nesse tipo de preparação que os entrevistados descobriram suas posições em campo, ou seja, como atuariam de modo a fazer frente a um poderio conjugado com outros membros da equipe. No corpo construído, incluíam-se: o comportamento em jogo, a roupa, a chuteira, as trocas de olhares, as solicitações de bola, manifestação de entusiasmo quando um gol ou uma tentativa é marcada, aperta-se a mão, abraça-se. Trata-se de uma inteligência do corpo no qual "o ser humano total” (HOLT, 2009, p. 342), ou seja, o corpo está em situação de ação e age com propriedades perceptivas do todo, das tensões, do ambiente, das movimentações em jogo.

Esses jogadores desenvolveram o esporte a partir de uma relação com o saber do corpo, como sujeitos que têm uma noção de si para além do esquema e imagem corporal limitados à noção das partes do corpo; apresentavam uma fenomenologia do corpo na sua totalidade de percepção humana (NÓBREGA, 2010). Esse corpo não vivia desconectado dos contextos socioculturais que produziam as relações marcadas ora pelas sociabilidades de gratidão e reconhecimentos, ora pelos significados de ser negro (marcado pela ausência de seus atributos humanos e culturais). Observe na memória seguinte:

Você conhece a história do pó de arroz do Fluminense? Eles tinham um jogador negro, e passaram pó de arroz nele pra ele entrar em campo para não ser vaiado. Por isso o Fluminense é considerado pó de arroz. Isso foi na década de 20 . Eu comecei a jogar na década de $60 . \mathrm{Na}$ minha época os negros já eram os grandes jogadores de futebol, nós jogamos numa época que os negros já eram aceitos no futebol. Eu pelo menos nunca sofri. Muito pelo contrário. (Depoente 1).

O preconceito no Brasil é um preconceito virtual. Ele é escondido. Mas é. Se você olha na TV, na copa, só mostrava loira, branca. Você não vê negra. Ou então o cara que filma é racista! Das duas uma! Porque não é só loira que vai ver futebol. Se você vai em um evento, as meninas que recebem vocês são loiras de olhos azuis. Você não vê uma preta lá... isso é uma história séria. [...]. (Depoente 2).

A memória dos jogadores destaca o racismo pelas vivências diretas e pela forma como a sociedade brasileira foi estruturada, ou seja, pela exploração de africanos negros trazidos ao Brasil de maneira forçada. Mas ao afirmar que o racismo existiu dessa forma na nossa sociedade, destaca que [ele] nunca vivenciou a discriminação racial devido ao futebol:

Sabemos que o racismo é da sociedade que se estruturou no sistema escravista, mas eu passei, nunca tive isso, nunca fui excluído nessa época. O futebol nos ajudou. Eu nunca fui chamado de negro no sentido pejorativo, as pessoas nos respeitavam muito, pelo valor que as pessoas nos davam no profissional, hoje em dia é que as pessoas não têm educação, querem até agredir o jogador do time que ele torce porque o jogador não jogou bem, porque o time perdeu, enfim as pessoas têm que melhorar muito. (Depoente 10).

Destaca-se que o racismo brasileiro, de fato, é difícil de ser constatado, devido a sua incorporação aos processos institucionais. É velado, escondido, como disse o Depoente 2; por isso, pode até ser confundido com a "rivalidade do futebol". Isto significa que os processos de racialização manifestados nas emoções desportivas (de tempos de lazer e excitação) estão disfarçados no teor da competitividade, sendo vivenciado mais na sua característica simbólica do que direta (de discriminação e exclusão).

Esse negócio de racismo que tinha aí quando nós jogava em Cuiabá e Campo Grande era a maior rivalidade, não sei se você já ouviu falar isso... Macaco era o nome que não saía da boca dos torcedores e quando vinham jogar aqui, mesma 
coisa. Era coisa de rivalidade de futebol, depois ia beber cerveja junto... Hoje em dia dá até cadeia. Não, a gente ficava quieto, ia falar o quê? A gente ria, tomava como uma gozação comum... (Depoente 4).

O imaginário social sobre raça - que guarda no racismo sua ideologia - evocado nos estádios de futebol pelo uso do termo "macaco", situação de injúria racial, ampara-se nos valores etnocêntricos de "homem", desenvolvidos pela "ciência" sobre diversidade humana criada nos séculos XVII e utilizada até o século XIX no Brasil. É significativo destacar que o termo racial "macaco" é extremamente ofensivo, pois, diz-se, assentado em um dispositivo mitológico, em que o negro permanece, segundo a concepção darwinista de evolução, imerso no plano primitivo [e] biológico do desenvolvimento humano. Dessa forma, ofende a pessoa, ao querer enfatizar uma dita condição biológica, naturalmente animalizada, apartada dos processos históricos de construção humana (SANTOS, 1983).

Ainda de acordo com essa autora, o mito é uma fala, um discurso — verbal ou visual, uma forma de comunicação. Mas o mito é uma fala que objetiva escamotear o real, produzir o ilusório, negar a história. É “[...] instrumento formal da ideologia, que pode entender-se como resultante da convergência de determinações econômico-político-ideológicas e psíquicas". É um conjunto de representações que resulta do "[...] funcionamento do psiquismo em que predomina o processo primário, o princípio do prazer e a ordem do imaginário" (SOUZA, 1983, p. 25).

Observe que no Brasil está em curso o desenvolvimento de uma outra consciência das relações raciais, especialmente com a articulação do movimento negro e dos centros de produção de conhecimento das universidades que culminaram nas políticas de Ação Afirmativa no Ensino Superior e nos currículos pela Lei n. 11.645/2008 (n. 10.639/2003). Entretanto, no período que nossos entrevistados atuaram como jogadores, pouco se discutia sobre racismos e seus significados. Como disse o ex-jogador: "vamos fazer o quê?". Outro ex-jogador lembra do racismo que se estabelecia nas relações entre branco e negro, vejamos:

Eu percebia, eu sentia, mas eu superava, eu sabia que tem aquela diferença do negro pro branco, eu via pela diferença de tratamento de um atleta branco com o atleta negro. Assim, o atleta negro era menosprezado, eu via determinados diretores, o tratamento; às vezes, dava mais atenção, mais carinho pro atleta branco, e eu passei por cima disso. Eu via a diferença fora do campo, havia mais contato, mais diálogo, mais carinho, até hoje eu sinto. Aí eu me imponho, sou oficial de justiça, sou autoridade, onde entro eu sou educado. Eu supero. [...] Nossa! o futebol abriu as portas... A mídia nacional, internacional expõe isso, (o racismo) mas existe até hoje. (Depoente 8).

Eu não sei se ainda existe. Eu acho que sim. Eu não sei por que, eu acho que tudo que aconteceu comigo foi através do jogo da bola, onde eu ia eu era bem tratado, igual meu compadre, onde chega é bem chegado. Mas a pessoa tem que saber chegar... Caso contrário, você tem que... não é porque... você tem que saber entrar e sair. Não é porque você é jogador de futebol que você pode entrar num aniversário, num ambiente familiar e fazer palhaçada. Isso até uma pessoa branca se fizer vai ser mandada embora. (Depoente 1).

De nossas análises de conversas com os ex-jogadores, observando suas expressões, vamos dizer que não se sobrepõem nas suas memórias as vivências do racismo; ao contrário, muito pouco se lembraram de sociabilidades pautadas no preconceito e na discriminação racial. $O$ que mais enfatizaram foram memórias de orgulho de si e reconhecimento pelo peso de suas ações como indivíduo no interior de um coletivo. As memórias pontuaram dificuldades, mas nunca barreiras intransponíveis... 
Fui criado no abrigo das crianças. Eu estudava e em dezembro, nas férias, eu voltava pro sítio, pra roça. Com 13 anos de idade, meu pai largou da minha mãe com oito filhos, quatro homens e quatro mulheres. Eu comecei a trabalhar para sustentar meus irmãos e minha mãe. Trabalhei na padaria de seu Antônio e depois fui pro quartel. Quando comecei jogar futebol, nós viemos para Cuiabá e eu trabalhava com um primo meu que era construtor, fui trabalhar com ele de ajudante. Nisso peguei amizade com o pessoal do bairro e eles me convidavam: "bora jogar bola, bora jogar bola" e eu comecei a jogar bola. Já jogava lá no abrigo, á fui jogar no Americano, do Americano fui pro Rodoviário, antes de eu entrar no Mixto. Mixto era o seguinte: a gente tinha que jogar bola a troco de emprego, porque nessa época recebia salário mínimo e tinha que pedir com 10 dias de antecedência para conseguir adiantamento de 200, 300 cruzeiros... Os caras de fora recebia tudo em dia... tinha esse esquema ainda... daí entrei na fiscalização e aí ficou bom, melhorou tudo. Trabalhei como diarista na Secretaria de Fazenda, mas foi o diretor financeiro do Mixto que me colocou lá. Ele era vice-presidente do Mixto. Fiquei de diarista porque nessa época não tinha concurso ainda, eu trabalhava no almoxarifado.

Era eu e Rômulo. Rômulo estudava e jogava e eu trabalhava e jogava. Estudei até o quarto ano primário, o que naquela época era algo bom. Tudo que eu tenho, amigo, família, tudo, agradeço ao futebol... Fui campeão várias vezes, a primeira vez é só alegria. O futebol abriu muitas oportunidades, mas depende da pessoa aproveitar. Logo que eu iniciei com 17 anos, joguei três anos no Americano, aí em 1960 fui pro Mixto, onde fiquei até 74. Nesses anos todos, quatorze anos no Mixto, o ano que não fui campeão eu fui vice. Teve um ano que saímos em terceiro lugar. Em 1964 deu um intervalo que eu joguei no time do Atlético Matogrossense, aí em 74 eu encerrei. Encerrei carreira e fiquei como preparador físico... aí quando faltava treinador eu ia ser treinador... do Mixto. Fiquei no Mixto até em 78 como treinador, preparador físico, auxiliar de treinador... Em 1970 eu casei e fui trabalhar na Secretaria de Fazenda, trabalhava de manhã e na parte da tarde ia para o treinamento físico. [Sr. Felizardo se retira da sala e volta com um violão] Ganhei um violão do China, a senhora ficou sabendo, né? China foi um músico dos anos 60 , eu não toco, faço barulho... Esse violão tem 55 anos... China era meu amicíssimo, ele queria presentear-me quando fui pro Mixto, aí ele pegou e me deu esse violão e eu retribuí ganhando títulos. (Depoente 7).

Observe na memória do ex-jogador uma história de orgulho e reconhecimento de seus talentos especiais pela sociedade, com pessoas que arranjavam postos de trabalhos para os jogadores de sucesso. Essas memórias coerentes com as realidades vividas, pois marcadas que estão pela história de vida, indicam reconhecimento de injustiças sofridas pelos jogadores da cidade, que enfrentavam dificuldades para receber seus ordenados, enquanto os de fora já vinham com contratos e os acordos financeiros acertados.

Apesar das táticas desenvolvidas pelos jogadores na luta pela sobrevivência mediante trabalho, e em conciliação com o futebol, percebemos que a raça foi vivida por esses ex-jogadores a partir de noções da "diferença cultural", na qual os significados subjacentes ao esporte como força, equilíbrio, mérito, qualificação do grupo como vencedor e suas atribuições simbólicas de campeão lograram relevância importante na memória, em detrimento dos sentidos de inferioridade racial, comumente imputados ao negro na sociedade brasileira.

Dessa forma, a memória coletiva desenvolve uma autêntica política de descentralização de poder (GILROY, 2001), pois as lembranças dos ex-jogadores destacam os heróis no futebol que foram e as pessoas "educadas", "políticas" e "vencedoras" que são. Trazem à tona, portanto, uma história que marca a força da singularidade que configuraram no coletivo de jogadores negros dessa época. Nesse sentido, de fato é pertinente dizer que a memória é o modo mais concreto de 
compreender o mundo, pois decorre de um encontro coletivo de pensamentos coerentes que pesam nos modos de se perceber como pessoa e como grupo.

Eu sei que o futebol tem dessas coisas, vou dizer pra você que eu sempre evitei, sair assim, nos clubes que era mais frequentado por pessoas que eram da elite, pra evitar certas coisas, porque eu sou negro, né? Mas, através da bola a gente era convidado e a gente ia meio receoso, mas sempre tinha um outro negro junto comigo, Glauco, eu acho que você vai falar com ele, Glauco é meu compadre. Então... mas sempre tinha os cara branco, né? A gente sempre foi recebido nas festas das pessoas que se diziam da elite. Sempre fomos bem tratados, graças a Deus. (Depoente 1).

Destaca-se a memória das relações étnico-raciais com significados paradoxais, os sentimentos de "medo" de não ser aceito "por isso evitava sair... ficava receoso"; e o sentimento de pertencimento a partir da diferença (de ser negro). Essa memória indica que a vivência da raça / cor poderia ser pela via da discriminação racial, mas, antes disso, a raça / cor emerge como força que liga os dois, que se sentem iguais na diversidade de pessoas. Nesse processo de identificação se reconhecem os valores, a ética e o comportamento como cruciais para ser bem aceito, "bem chegado".

Não se conta uma história de sofrimentos, mas de superações, de processos de libertação. Não se trata de uma contradição, mas da existência de complexidades que dão sentidos às ações dos indivíduos, pois dizemos com Arendt (1978 ) que a memória é um poder do espírito e, por isso, pesa e se torna tão importante na reconstituição do grupo, pois tem o poder de criar novas direções.

\section{CONSIDERAÇÕES}

A memória coletiva de ex-jogadores negros se pauta nas formas de ligação e identificação que o futebol possibilitou no tempo e espaço de vivências de particularidades raciais que eram ancoradas nas virtudes de ser campeão e negro, fato que se configura na constituição subjetiva do negro, que utilizou a prática corporal como modo de organização e fortalecimento contra a subordinação racial. A despeito do desgosto das vivências raciais em campo, ser jogador campeão de futebol recebia uma designação de valor de trabalho artístico, de poder e de reconhecimento. Dessa forma, para alguns jogadores, as questões raciais comumente vivenciadas pela violência racista na sociedade mais ampla eram facilmente diluídas, pois desenvolviam em torno de si valores que emergiam do reconhecimento que caracteriza o esporte de sucesso como força, vitalidade, equilíbrio, positividade, alegria, solidariedade etc.

Nesse sentido, podemos afirmar que o futebol como prática social esportiva contribuiu para a constituição da identidade negra, compreendida como construção social, histórica e cultural. A partir das lembranças, a identidade apresenta-se implicada com a reconstrução do olhar de um grupo étnico-racial que reconhece a si mesmo na relação com o outro. O processo de ascensão social do negro adquire significado de libertação do lugar de marginalização social. Mas a memória (coletiva) se distingue pela possibilidade de se pautar como sujeito na história do esporte.

Percebemos que as memórias dos ex-jogadores se apresentam em coerência com os acontecimentos e que se valem da memória como consciência e pensamento reflexivo para reinscrever sua história do lugar de quem fez e vivenciou o esporte. Esse processo rompe com a noção do negro em posição de subalternidade para passar a uma noção de empoderamento. Nesse sentido, o estudo aponta para a importância da memória na constituição de identidades, coletividades e garantia de direitos.

\section{REFERÊNCIAS}

Revista Teias v. 21 • n. 62 • jul./set. 2020 • Seção Temática Raça e Cultura 
ARENDT, Hannah. A vida do espirito: v. II - Querer. Lisboa: Instituto Piaget, 1978.

ARREGUY, Marília Etienne. Ensaio para uma exegese da emoção e da paixão nos amores trágicos. In: FARIAS, Francisco Ramos (org.). Apontamentos em memória social. Rio de Janeiro: Contra Capa, 2011.

BOSI, Éclea. Memória e sociedade lembranças de velhos. São Paulo: Companhia das Letras, 1994.

BRASIL. LDB 9.394/96 - Lei de Diretrizes e Bases da Educação Brasileira com a inserção da Lei 10.639/03. Disponível em http://www.planalto.gov.br/ccivil 03/leis/2003/110.639.htm. Acesso em 23 fev. 2020.

COSTA, Jurandir Freire. Da cor ao corpo: a violência do racismo. In: SANTOS, Neusa Sousa. Tornar-se negro: as vicissitudes da identidade do negro brasileiro em ascensão social. Rio de Janeiro: Graal, 1983.

DIAS, José Dias. Hannah Arendt e Nietzsche: possibilidades de um estudo sobre memória, a criação e a liberdade. In: FARIAS, Francisco Ramos (org.). Apontamentos em memória social. Rio de Janeiro: Contra Capa, 2011.

ELIAS, Norbert; DUNNING, Eric. A busca da excitação. Lisboa: Difel, 1992.

FRANCO Júnior, Hilário. A dança dos deuses: futebol, cultura, sociedade. São Paulo: Companhia das Letras, 2007.

FRAGA, Branco Alex. Anatomias emergentes e o bug muscular: pedagógicas do corpo no limiar do século XXI. In: SOARES, Carmem Lúcia (org.). Corpo e história. Campinas, São Paulo: Autores Associados, 2004. p. 61-78.

GILROY, Paul. O Atlântico negro. Modernidade e dupla consciência. Tradução de Cid Knipel Moreira. UCAM - Centro de Estudos Afro-Asiáticos. Rio de Janeiro: Editora 34, 2001.

GONÇALVES, Marlene. Fragmentos da memória subterrânea das usinas de açúcar: Aricá, Conceição, Fechas e Maravilha. Curitiba, Paraná: CRV, 2011.

HALBWACHS, Maurice. Memória coletiva. São Paulo: Centauro, 2006.

HALL, Stuart. Estudos culturais: dois paradigmas. In: SOVIK, Liv (org.). Da diáspora. Identidades e mediações culturais. Tradução Adelaine La Guardia Resende et al. Belo Horizonte, Brasília: Ed. UFMG: Unesco Brasil, 2003.

HASENBALG, Carlos; SILVA, Nelson Valle. Cor e estratificaşão social. Rio de Janeiro: Contra Capa Livraria, 1999.

HOLT, Richard; VIGARELLO, Georges. O corpo trabalhado - ginastas e esportistas no século XIX. In: CORBIN, Alain; COURTINE, Jean-Jaques; VIGARELLO, Georges (orgs.). História do corpo: da Revolução à Grande Guerra. Tradução de João Batista Kreuch, Jaime Clasen. 3. ed. Petrópolis, Rio de Janeiro: Vozes, 2009. p. 393-478.

MURAD, Maurício. Dos pés à cabeça. Elementos básicos de sociologia do futebol. Rio de Janeiro: Irradiação Cultural, 1996.

NOBREGA, Terezinha Petrucia da. Uma fenomenologia do corpo. São Paulo: Ed. Livraria da Física, 2010.

PIMENTA, Carlos Alberto Máximo. As transformações na estrutura do futebol brasileiro: o fim das torcidas organizadas no estádio de futebol. In: COSTA, Márcia Regina da et al. (orgs.). Futebol espetáculo do século. São Paulo: Musa Editora, 1999. p. 131-145.

PINHO, Vilma Aparecida de. Jovens negros em processo de "ressocialização": trajetórias de vida e escolarização. 2010. 250 f. Tese (Doutorado em Educação) - Programa de Pós-Graduação em Educação, Universidade Federal Fluminense, Niterói. 2010. 
PINHO, Vilma Aparecida de; GRUNENNVALDT, José Tarcísio. O futebol e o negro: sociedade e cultura no esporte em Cuiabá. Programa de Pós-Graduação em Educação Física, Relatório de Pósdoutorado, 2018.

POLLAK, Michael. Memória, esquecimento, silêncio. Estudos Históricos. Rio de Janeiro. v. 2. n. 5; 1989. p. 3-15.

RODRIGUES FILHO, Mário. O negro no futebol brasileiro. Rio de Janeiro: Firmo, 2003.

SANTOS, Neusa Sousa. Tornar-se negro: as vicissitudes da identidade do negro brasileiro em ascensão social. Rio de Janeiro: Graal, 1983.

SKIDMORE, Tomas. Preto no branco: raça e nacionalidade no pensamento brasileiro. Rio de Janeiro: Paz e Terra, 1976.

THOMPSON Paul. A voz do passado. História oral. Tradução de Lólio Lourenço de Oliveira. 3. ed. Rio de Janeiro: Paz e Terra, 2002.

Submetido em marco de 2020 Aprovado em maio de 2020

\section{Informações do(a) autor(a)}

Vilma Aparecida de Pinho

Universidade Federal do Pará, Programa de Pós-Graduação em Educação e Cultura, Faculdade de Educação - Campus de Altamira

E-mail: vilmaaparecidadepinho@gmail.com

ORCID: https://orcid.org/0000-0002-2544-0841

Link Lattes: http://lattes.cnpq.br/2018069654110698

José Tarcísio Grunennvaldt

Universidade Federal do Mato Grosso, Faculdade de Educação Física

E-mail: jotagrun@hotmail.com.br

ORCID: https://orcid.org/0000-0002-5040-2679

Link Lattes: http://lattes.cnpq.br/6408231293460084 